\title{
Pengaruh Tipe Kelahiran terhadap Produksi Susu, Lama Laktasi, Masa Kering, Masa Kosong, dan Selang Beranak Kambing Saanen
}

\author{
The Effect of Saanen Doe Goats'Birth Types on Milk Yields, Lactation Length, Dry Period, Days Open, and \\ Kidding Interval \\ Yudi $^{1 *}$, A. Atabany ${ }^{2}$, \& B. P. Purwanto ${ }^{3}$ \\ ${ }^{1}$ Sekolah Pascasarjana, Departemen Ilmu Produksi dan Teknologi Peternakan, Fakultas Peternakan, Institut \\ Pertanian Bogor \\ ${ }^{2}$ Departemen Ilmu Produksi dan Teknologi Peternakan, Fakultas Peternakan, Institut Pertanian Bogor \\ Jl. Agatis, Kampus Dramaga, Bogor 16680 \\ ${ }^{3}$ Sekolah Vokasi, Institut Pertanian Bogor, Jl. Kumbang No. 14 Bogor 16151 \\ *Corresponding author: yudi2302osaka@gmail.com \\ (Received 26-04-2021; Revised 31-05-2021; Accepted 10-06-2021)
}

\begin{abstract}
The purpose of this research was to determine the effect of Saanen doe goats' birth types on milk yields, lactation length, dry period, days open and kidding interval at PT Fajar Taurus. This research employed a case study method using secondary data of production and reproduction of Saanen doe goats. Data was analysed using Microsoft Excel program and Kruskal Wallis test. The results showed percentages of Saanen doe goats with single, twinning and triplets birth are $47.94 \%, 39.73 \%$ and $12.33 \%$ respectively. Milk yields for single birth was $1,14 \pm 0,43$ litres/goat/day, lactation length of $286.43 \pm 119.73$ days, dry period of $68.89 \pm 18.57$ days, days open of 205.31 \pm 117.67 days, and kidding interval of $355.31 \pm 117.67$ days. Milk yields for twinning birth was $1.32 \pm 0.49$ litres/goat/day, lactation length of $270 \pm 219.43$ days, dry period of $69.10 \pm 17.52$ days, days open of $189.10 \pm 227.22$ days, and kidding interval of 339.10 \pm 227.22 days. Meanwhile, milk yields for triplets birth was $0.93 \pm 0.40$ litres/goat/day, lactation length of $360 \pm 228.97$ days, dry period of $66.67 \pm 23.78$ days, days open of $276.67 \pm 240.38$ days, and kidding interval of $426.67 \pm 240.38$ days. There is nonsignificant effect of birth types on milk yields, lactation length, days open and kidding interval in Saanen doe goats $(\mathrm{P}>\mathbf{0 . 0 5})$. However, birth types were found to have a significant effect on dry period $(\mathrm{P}<0.05)$.
\end{abstract}

Keywords: Birth Type, Kidding Interval, Lactation Length, Milk Yields, Saanen.

\section{ABSTRAK}

Penelitian ini bertujuan mengetahui pengaruh tipe kelahiran terhadap produksi susu, lama laktasi, masa kering, masa kosong dan selang beranak kambing Saanen, di PT Fajar Taurus. Metode penelitian studi kasus menggunakan data sekunder, data produksi dan reproduksi kambing Saanen induk. Data dianalisis menggunakan program Microsoft Excel dan uji Kruskal Wallis. Hasil penelitian menunjukkan persentase kelahiran tunggal $\mathbf{4 7 . 9 4 \%}$, kembar dua $39.73 \%$, dan kembar tiga $\mathbf{1 2 . 3 3 \%}$. Produksi susu induk tipe kelahiran tunggal $1.14 \pm 0.43$ liter/ekor/hari, lama laktasi $286.43 \pm 119.73$ hari, masa kering 68.89 \pm 18.57 hari, masa kosong $205.31 \pm 117.67$ hari, dan selang beranak $355.31 \pm 117.67$ hari. Produksi susu induk tipe kelahiran kembar dua $1.32 \pm 0.49$ liter/ekor/hari, lama laktasi $270 \pm 219.43$ hari, masa kering 69.10 \pm 17.52 hari, masa kosong 189.10 \pm 227.22 hari, dan selang beranak 339.10 \pm 227.22 hari. Sedangkan, produksi susu induk tipe kelahiran kembar tiga $0.93 \pm 0.40$ liter/ekor/hari, lama laktasi $360 \pm 228.97$ hari, masa kering 66.67 \pm 23.78 hari, masa kosong 276.67 \pm 240.38 hari dan selang beranak $426.67 \pm 24038$ hari. Tipe kelahiran tidak berpengaruh nyata terhadap produksi susu, lama laktasi, masa kosong, selang beranak $(\mathrm{P}>0.05)$. Namun berpengaruh nyata terhadap masa kering kambing Saanen $(\mathrm{P}<0.05)$.

Kata kunci: Kambing Saanen, Lama Laktasi, Produksi Susu, Selang Beranak, Tipe Kelahiran. 


\section{PENDAHULUAN}

Peternak kambing rakyat di pedesaan menjadikan kambing sebagai ternak potensial bagi perekonomian mereka. Saat ini, lebih dari satu miliar kambing dikembangbiakan sebagai penghasil daging dan susu di seluruh dunia, terutama di negara-negara berkembang di Asia dan Afrika. Asia adalah negara tempat kambing liar mulai didomestikasi yang telah menampung lebih dari setengah miliar populasi kambing di dunia (Liang dan Paengkoum 2019). Kambing Saanen adalah salah satu bangsa kambing perah yang diimpor dari Australia dan dikembangkan di Indonesia. Menurut Faye dan Konuspayeva (2012) Saanen berasal dari negara sub tropis akan lebih baik dipelihara secara intensif. Silva et al. (2011) mengatakan bahwa melalui respon fisiologis Saanen mampu beradaptasi pada kondisi lingkungan baru yang dapat mempengaruhi performa produksinya. Sedangkan Beth dan Christopher (2019) mengatakan keunggulan Saanen adalah pada produksi susu, genetik, produktivitas, adaptasi dan toleran terhadap kondisi pakan yang jelek. Menurut Yilmaz et al. (2016) rata-rata produksi susu Saanen tertinggi dibandingkan dengan kambing perah lainnya.

Tipe kelahiran adalah salah satu kriteria kesuburan ternak kambing. Kambing tipe perah, tipe kelahiran tunggal lebih tinggi daripada tipe kelahiran kembar dua dan kembar tiga, tapi kelahiran kembar sangat diharapkan, karena menguntungkan. Saanen memiliki lama laktasi 272-312 hari (Makin 2014). Melalui pergantian sel-sel kelenjar selama masa kering dapat dihasilkan kapasitas produksi susu yang optimal pada laktasi berikutnya (Collier et al. 2011). Panjangnya selang beranak, saling berkaitan antara masa kosong dengan selang beranak, masa kosong yang panjang menunjukkan selang beranak yang panjang. Semakin cepat ternak bunting kembali setelah beranak akan semakin pendek masa kosong dan selang beranak. Selang beranak kambing perah antara 165-370 hari (Makin 2014).

Pemeliharaan kambing perah Saanen di Indonesia sebagai sebuah usaha membutuhkan jenis kambing perah yang memiliki performa yang dapat dioptimalkan. Oleh karena itu, penelitian tentang pengaruh tipe kelahiran tunggal, kembar dua dan kembar tiga dilakukan untuk membandingkan dan melihat pengaruhnya terhadap produksi susu, lama laktasi, masa kering, masa kosong dan selang beranak pada kambing perah Saanen.

\section{MATERI DAN METODE}

\section{Waktu dan Lokasi Penelitian}

Penelitian ini dilaksanakan pada bulan Desember 2020, di PT Fajar Taurus, Desa Benda Kecamatan Cicurug Kabupaten Sukabumi Jawa Barat.

\section{Materi}

Materi dalam penelitian ini adalah data populasi kambing Saanen 73 ekor, dari periode laktasi I, II, III, dan IV. Data tipe kelahiran tunggal 35 data, kembar dua 29 data, dan tipe kelahiran kembar tiga 9 data, yaitu data catatan produktivitas pada produksi susu, lama laktasi, masa kering, masa kosong dan selang beranak kambing Saanen induk dari tiga tipe kelahiran yang dipelihara dari tahun 1999 sampai 2003.

\section{Prosedur Penelitian}

Pengambilan data pada penelitian ini adalah mengambil semua data produksi dan reproduksi dari 4 periode laktasi. Kemudian melakukan seleksi terhadap data dan mengambil data yang lengkap. Setiap tipe kelahiran akan dibandingkan dan dijadikan sebagai prediktor untuk mengetahui pengaruhnya terhadap produksi susu, lama laktasi, masa kering, masa kosong dan selang beranak.

\section{Peubah dan Cara Pengukurannya}

1. Tipe kelahiran adalah jenis kelahiran seekor induk dari setiap kelahiran tunggal, kembar dua dan kembar tiga, dalam satuan ekor.

2. Produksi susu dihitung dari total produksi susu selama satu periode laktasi dibagi lama laktasi, dalam satuan liter.

3. Lama laktasi dihitung dari catatan tanggal pertama kali kambing diperah sampai tanggal terakhir kambing tersebut diperah, dalam satuan hari.

4. Masa kering dihitung dari tanggal terakhir induk diperah sampai tanggal induk beranak, dalam satuan hari.

5. Masa kosong dihitung dari tanggal awal induk beranak sampai tanggal induk kawin dan terjadi kebuntingan, dalam satuan hari.

6. Selang beranak dihitung dari tanggal induk beranak pertama sampai dengan tanggal induk beranak berikutnya, dalam satuan hari.

\section{Analisis Data}

Data dideskripsikan terhadap nilai minimum, nilai maksimum, rata-rata, standar deviasi, dan koefisien variasi. Uji Kruskal Wallis digunakan untuk melihat pengaruh peubah yang diamati antara induk kambing Saanen dari tipe kelahiran tunggal, kembar dua, dan kembar tiga.

Statistik uji Kruskal Wallis

a. Tanpa faktor koreksi:

$$
H=\frac{12}{N(N+1)} \sum \frac{R_{J}^{2}}{n_{J}}-3(N+1)
$$

b. Dengan faktor koreksi (jika ada sampel bernilai sama)

$$
H=\frac{\frac{12}{N(N+1)} \sum \frac{R_{J}^{2}}{n_{J}}-3(N+1)}{1-\frac{\sum t^{3}-t}{N^{3}-N}}
$$

Keterangan:

$\mathrm{R}_{\mathrm{j}} \quad=$ Jumlah ranking per kondisi/perlakuan.

$\mathrm{n}_{\mathrm{j}} \quad=$ Banyaknya kasus per $\mathrm{j}$.

$\mathrm{t}=$ Banyaknya observasi berangka sama dalam data.

$\mathrm{N} \quad=$ Banyaknya kasus.

Keputusan: Jika $\mathrm{H} \leq$ Ho, Terima Ho dan jika $\mathrm{H}>$ Ho, Tolak Ho. 


\section{HASIL DAN PEMBAHASAN}

\section{Tipe Kelahiran Kambing Saanen di PT Fajar Taurus}

Tipe kelahiran adalah jenis kelahiran dari seekor induk pada setiap kelahiran, yaitu tunggal, kembar dua dan kembar tiga. Tipe kelahiran kambing Saanen yang terjadi di PT Fajar Taurus dapat dilihat pada Tabel 1.

Tabel 1. Tipe kelahiran kambing Saanen

\begin{tabular}{|c|c|c|c|c|c|c|c|c|}
\hline \multirow{2}{*}{$\begin{array}{c}\text { Tipe } \\
\text { Kelahiran }\end{array}$} & \multicolumn{4}{|c|}{ Periode Laktasi } & \multirow[t]{2}{*}{ Jumlah } & \multirow[t]{2}{*}{ Rataan } & \multirow{2}{*}{$\begin{array}{l}\text { Std. } \\
\text { dev }\end{array}$} & \multirow[t]{2}{*}{$\%$} \\
\hline & I & II & III & IV & & & & \\
\hline Tung؛ & 21 & 5 & 5 & 4 & 35 & 9 & 8.64 & 47.94 \\
\hline Kembar 2 & 8 & 8 & 6 & 7 & 29 & 7 & 0.82 & 39.73 \\
\hline Kembar 3 & - & 5 & 4 & - & 9 & 2.25 & 2.63 & 12.33 \\
\hline
\end{tabular}

Berdasarkan Tabel 1, tipe kelahiran kambing Saanen dari periode laktasi pertama sampai periode laktasi keempat induk melahirkan tunggal 35 ekor (47.94\%) lebih tinggi dari induk yang melahirkan kembar dua 29 ekor (39.73\%) dan kembar tiga 9 ekor (12.33\%). Sama halnya dengan hasil penelitian Ince (2010) bahwa proporsi kelahiran kembar kambing Saanen lebih rendah 42.3\% dari kelahiran tunggal $57.7 \%$. Hasil penelitian yang dilakukan di PT Fajar Taurus ini menunjukkan semakin bertambahnya periode laktasi, jumlah kelahiran dan kelahiran kembar semakin menurun. Kejadian ini karena umur ternak sudah melewati batas umur produktif, kemampuan dan kapasitas induk memelihara kebuntingan kembar, tatalaksana pakan dan asupan nutrisi yang mempengaruhi sistem reproduksi induk. Bertambahnya umur induk, bobot badan, dan paritas berpengaruh positif terhadap tingkat kelahiran (Haldar et al. 2014). Gangguan reproduksi dan menurunnya reproduktivitas induk beranak kembar dapat memperpendek masa produktif induk selama 200 hari (Lopez-Gautius et al. 2017).

\section{Pengaruh Tipe Kelahiran terhadap Produksi Susu}

Produksi susu yang dihasilkan oleh seekor ternak dapat dipengaruhi oleh tipe kelahiran, dimana peningkatan jumlah anak yang dilahirkan menyebabkan peningkatan jumlah susu yang dihasilkan. Deskripsi data produksi susu dari tipe kelahiran tunggal, kembar dua dan kembar tiga di PT Fajar Taurus dapat dilihat pada Tabel 2.

Berdasarkan deskripsi data Tabel 2, rataan produksi susu induk tipe kelahiran kembar dua adalah tertinggi $1.32 \pm 0.49$ liter/ekor/hari, koefisien variasi 37.04\%, sedangkan produksi susu induk tipe kelahiran kembar tiga $0.93 \pm 0.40$ liter/ekor/hari, koefisien variasi $43.39 \%$, lebih rendah daripada produksi susu tipe kelahiran tunggal $1.14 \pm 0.43$ liter/ekor/hari dengan koefisien variasi $37.67 \%$. Hasil penelitian Bermejo et al. (2020) rataan produksi susu kambing Saanen per ekor per hari untuk tipe kelahiran tunggal $1.34 \pm 0.01 \mathrm{~kg}$, tipe kelahiran kembar dua $1.51 \pm 0.01$ $\mathrm{kg}$ dan tipe kelahiran kembar tiga $1.62 \pm 0.03 \mathrm{~kg}$. Pada hasil penelitian produksi susu dari tipe kelahiran kembar dua menunjukkan peningkatan 0.18 liter/ekor/hari atau $5.31 \%$ dibandingkan dengan produksi susu tipe kelahiran tunggal. Litter size meningkat diikuti oleh peningkatan perkembangan mammae di akhir bunting induk. Melahirkan kembar cenderung mempengaruhi tingkat produksi susu induk $20-25 \%$, artinya sekitar $12 \%$ lebih banyak dari susu induk yang melahirkan tunggal (Assan 2020).

Peningkatan produksi susu hanya terjadi pada induk tipe kelahiran kembar dua sedangkan pada kembar tiga terjadi penurunan, karena bobot badan induk yang rendah, kesehatan induk, dan pakan yang tidak mencukupi kebutuhan sehingga mempengaruhi tingkat produksi susu yang dihasilkan induk. Bobot badan induk yang melahirkan kembar tiga cenderung lebih rendah dari kelahiran tunggal dan kembar dua, produksi susu akan turun sebesar 13.7\%, distosia, kematian dan keguguran adalah penyebabnya (Kusaka et al. 2017). Terbatasnya mobilisasi energi ke jaringan berdampak pada asupan nutrisi yang terbatas untuk produksi susu, karena diawali oleh kondisi induk yang mengalami stress setelah melahirkan (Goetsch 2011).

Tabel 3. Hasil statistik uji kruskal wallis produksi susu dari tipe kelahiran tunggal, kembar dua, dan kembar tiga

Kruskal wallis rank

\begin{tabular}{cccc}
\hline & Tipe Kelahiran & N & Mean Rank \\
\hline Produksi susu & Tunggal & 35 & 35.03 \\
& Kembar dua & 29 & 42.79 \\
& Kembar tiga & 9 & 26.00 \\
& Total & 73 & \\
\hline
\end{tabular}

\begin{tabular}{|c|c|c|}
\hline & Test s & $\mathrm{CS}^{\mathrm{a}, \mathrm{b}}$ \\
\hline & Nilai & \\
\hline Chi Square & 4.885 & $->\mathrm{H}_{\text {tabel }}$ \\
\hline Df & 2 & \\
\hline Asymp. Sig & 0.087 & $->\mathrm{H}_{\text {hitu }}$ \\
\hline
\end{tabular}

Berdasarkan statistik dapat dilihat pada Tabel 3, hasil analisis uji Kruskal wallis menunjukkan bahwa tipe kelahiran pengaruhnya tidak nyata terhadap produksi susu $\mathrm{H}_{\text {hitung }}<\mathrm{H}_{\text {tabel }}(0.087<4.885)$. Menurut Assan (2020) tingginya produksi susu yang dihasilkan oleh seekor induk kambing dapat dipengaruhi tipe kelahiran dan ada faktor non genetik

Tabel 2. Rataan produksi susu kambing Saanen

\begin{tabular}{lcccccc}
\hline Tipe Kelahiran & $\mathrm{n}$ & Produksi Susu (liter) & Std. dev & Koefisien variasi (\%) & Minimum (liter) & Maksimum (liter) \\
\hline Tunggal & 35 & 1.14 & 0.43 & 37.67 & 0.50 & 2.22 \\
Kembar 2 & 29 & 1.32 & 0.49 & 37.04 & 0.46 & 2.52 \\
Kembar 3 & 9 & 0.93 & 0.40 & 43.39 & 0.44 & 1.56 \\
\hline
\end{tabular}


Yudi et al.

Jurnal Ilmu Produksi dan Teknologi Hasil Peternakan 9 (2): 102-109

Tabel 4. Rataan lama laktasi kambing perah Saanen

\begin{tabular}{lcccccc}
\hline Tipe Kelahiran & $\mathrm{n}$ & Lama Laktasi (hari) & Std. dev & Koefisien variasi (\%) & Minimum (hari) & Maksimum (hari) \\
\hline Tunggal & 35 & 286.43 & 119.73 & 41.80 & 150 & 630 \\
Kembar 2 & 29 & 270.00 & 219.43 & 81.27 & 150 & 1350 \\
Kembar 3 & 9 & 360.00 & 228.97 & 63.60 & 150 & 720 \\
\hline
\end{tabular}

yang mempengaruhi tingkat produksi susu, yaitu kondisi mikroklimat dan pengaturan nutrisi yang dibutuhkan oleh induk produktif.

\section{Pengaruh Tipe Kelahiran terhadap Lama Laktasi}

Lama laktasi adalah lamanya waktu induk kambing memproduksi air susu yang diawali setelah melahirkan sampai terakhir kambing perah tersebut dihentikan pemerahannya. Deskripsi data lama laktasi kambing Saanen dari tipe kelahiran tunggal, kembar dua dan kembar tiga di PT Fajar Taurus dapat dilihat pada Tabel 4.

Berdasarkan deskripsi data Tabel 4, rataan lama laktasi induk tipe kelahiran kembar tiga adalah terpanjang $360 \pm 228.97$ hari, koefisien variasi $63.60 \%$, sedangkan lama laktasi tipe kelahiran kembar dua $270 \pm 219.43$ hari, koefisien variasi $81.27 \%$, lebih pendek daripada lama laktasi tipe kelahiran tunggal $286.43 \pm 119.73$ hari, dengan koefisien variasi $41.80 \%$. Secara statistik hasil uji Kruskal wallis menunjukkan tipe kelahiran tidak berpengaruh terhadap lama laktasi. Namun koefisien variasi lama laktasi pada tipe kelahiran kembar dua lebih besar dari kelahiran tunggal dan kembar tiga, hal ini terjadi karena lama laktasi pada tipe kelahiran kembar dua lebih beragam. Koefisien keragaman yang tinggi menandakan bahwa sifat produksi sangat dipengaruhi oleh genetik ternak, karena pemeliharaan dan pada lokasi yang sama. Untuk mengurangi keragaman maka harus dilakukan seleksi dan afkir.

Tabel 5. Hasil statistik uji kruskal wallis lama laktasi dari tipe kelahiran tunggal, kembar dua, dan kembar tiga

Kruskal wallis rank

\begin{tabular}{llcc}
\hline & Tipe Kelahiran & N & Mean Rank \\
\hline Produksi susu & Tunggal & 35 & 39.93 \\
& Kembar dua & 29 & 32.69 \\
& Kembar tiga & 9 & 39.50 \\
& Total & 73 & \\
\hline
\end{tabular}

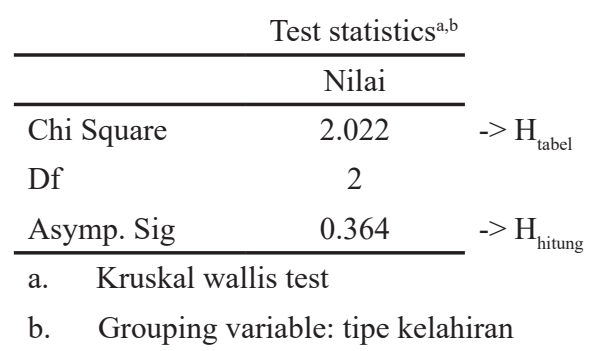

Menurut Anggraeni (2012) identifikasi keunggulan genetik ternak melalui seleksi adalah penting, terutama terhadap sifat yang diinginkan. Diketahui pula bahwa secara internal atau biologis produksi susu dapat dipengaruhi oleh lama laktasi. Margatho et al. (2019) mengatakan bahwa induk kambing melahirkan kembar memiliki rata-rata produksi susu lebih tinggi yang diikuti oleh lama laktasi lebih panjang daripada kelahiran tunggal. Fernandez (2013) juga mengatakan bahwa kambing perah memiliki panjang laktasi lebih panjang dari kambing tujuan ganda, yaitu susu dan daging, yang cenderung laktasinya pendek, juga fase laktasi dan tingginya produksi satu masa laktasi dapat memperpanjang lama laktasi.

Berdasarkan statistik dapat dilihat pada Tabel 5, hasil analisis uji Kruskal wallis menunjukkan tipe kelahiran pengaruhnya tidak nyata terhadap lama laktasi $\mathrm{H}_{\text {hitung }}<\mathrm{H}_{\text {tabel }}$ $(0.364<2.022)$. Menurut Sánchez et al. (2006) lama laktasi yang pendek pada kambing kelahiran kembar menunjukkan produksi susu yang lebih tinggi per hari dibandingkan tipe kelahiran tunggal. Artinya lama laktasi, dan produksi susu saling berhubungan dengan tipe kelahiran. Menurut Simões dan Pieres (2017) laktasi kambing Transmontano secara negatif nyata dapat dipengaruhi oleh gangguan reproduksi. Gaddour et al. (2007) mengatakan bahwa bangsa, lingkungan, dan nutrisi pakan berpengaruh terhadap tingkat produksi susu. Sedangkan menurut Tiezzi et al. (2012), panjang pendeknya lama laktasi adalah konsekuensi dari baik buruknya fertilitas induk setelah melahirkan.

Tabel 6. Hasil statistik uji kruskal wallis masa kering dari tipe kelahiran tunggal, kembar dua, dan kembar tiga

Kruskal wallis rank

\begin{tabular}{llcc}
\hline & Tipe Kelahiran & N & Mean Rank \\
\hline Masa kering & Tunggal & 35 & 36.46 \\
& Kembar dua & 29 & 37.67 \\
& Kembar tiga & 9 & 36.94 \\
& Total & 73 & \\
\hline
\end{tabular}

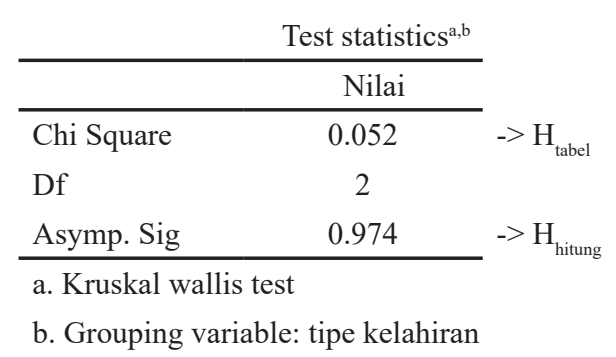

\section{Pengaruh Tipe Kelahiran terhadap Masa Kering}

Berdasarkan statistik dapat dilihat pada Tabel 6, hasil analisis uji Kruskal wallis menunjukkan tipe kelahiran pengaruhnya nyata terhadap masa kering Hhitung $<$ Htabel (0.974>0.052). Menurut Zobel et al. (2015) mengatakan 
Tabel 7. Rataan masa kering kambing perah Saanen

\begin{tabular}{lcccccc}
\hline Tipe Kelahiran & $\mathrm{n}$ & Masa Kering (hari) & Std. dev & Koefisien variasi (\%) & Minimum (hari) & Maksimum (hari) \\
\hline Tunggal & 35 & 68.89 & 18.57 & 26.96 & 32 & 100 \\
Kembar 2 & 29 & 69.10 & 17.52 & 25.35 & 29 & 102 \\
Kembar 3 & 9 & 66.67 & 23.78 & 35.67 & 16 & 95 \\
\hline
\end{tabular}

masa kering sangat terkait dengan kebijakan manajemen yang ditetapkan oleh setiap peternak. Pertimbangannya adalah proses masa kering pada ternak perah menyangkut kesejahteraan, kesehatan dan biologis ternak. Artinya masa kering memainkan peran penting dalam persiapan kelahiran dan tingkat produksi susu. Assan (2020) mengatakan ada kecenderungan kelahiran kembar dapat meningkatkan produksi susu induk.

Masa kering penting untuk menjaga kebuntingan dan mencapai produksi susu yang optimal pada laktasi berikutnya. Deskripsi data masa kering kambing Saanen dari tipe kelahiran tunggal, kembar dua dan kembar tiga di PT Fajar Taurus dapat dilihat pada Tabel 7.

Berdasarkan deskripsi data Tabel 7, rataan masa kering induk tipe kelahiran kembar dua adalah terpanjang $69.10 \pm 17.52$ hari, koefisien variasi $25.35 \%$, sedangkan masa kering tipe kelahiran kembar tiga $66.67 \pm 23.78$ hari, koefisien variasi $35.67 \%$, lebih pendek daripada masa kering tipe kelahiran tunggal $68.89 \pm 18.57$ hari dengan koefisien variasi $26.92 \%$. Menurut Fitriyanto et al. (2013) masa kering kambing PE terjadi minggu ke 12 atau bulan ke 3 kebuntingan. Perbedaan panjang masa kering, karena terkait kebijakan manajemen masa kering yang ditetapkan oleh perusahaan, diantaranya dilakukan sampai induk tidak memproduksi susu, apabila produksi susu induk masih tinggi dan sudah waktunya dikeringkan maka dilakukan penurunan secara bertahap dengan mengatur pemberian pakan sampai produksi susu induk turun, maksimal setiap kali pemerahan hanya menghasilkan $10 \mathrm{ml}$, dan masa kering dengan menghitung masa kebuntingan induk setelah umur bunting 4 bulan, maka induk wajib dilakukan masa kering selama 1 bulan sebelum kelahiran untuk memberikan kesempatan induk beristirahat, mempersiapkan kolostrum agar lebih berkualitas dan diharapkan kapasitas produksi susu pada laktasi berikutnya meningkat.

Menurut Hernandez et al. (2012) induk yang sedang laktasi harus diberikan waktu istirahat memperbaiki jaringan mammae. Perlakuan ini dilakukan untuk menjaga kesehatan metabolisme. Pengaturan masa kering yang sesuai agar fetus tidak bermasalah dengan kebutuhan energi pada saat sedang tumbuh sebelum kelahiran, dan terpenuhinya kebutuhan untuk metabolisme produksi susu setelah melahirkan.

\section{Pengaruh Tipe Kelahiran terhadap Masa Kosong}

Masa kosong adalah jarak antara melahirkan sampai dengan kawin menghasilkan kebuntingan. Deskripsi data masa kosong kambing Saanen dari tipe kelahiran tunggal, kembar dua dan kembar tiga di PT Fajar Taurus dapat dilihat pada Tabel 8 .

Berdasarkan deskripsi data Tabel 8, rataan masa kosong induk tipe kelahiran kembar tiga adalah terpanjang $276.67 \pm 240.38$ hari, koefisien variasi $86.88 \%$. Masa kosong tipe kelahiran kembar dua lebih pendek 189.10 \pm 227.22 hari, koefisien variasi $120.16 \%$ daripada masa kosong tipe kelahiran tunggal $205.31 \pm 117.67$ hari, dengan koefisien variasi 57.31\%. Hasil penelitian masa kosong dari ketiga tipe kelahiran lebih panjang dari hasil penelitian Pan et al. (2015) masa kosong kambing tipe kelahiran tunggal $94.44 \pm 2.93$ hari, kembar dua $103.95 \pm 2.29$ hari, dan kembar tiga $97.89 \pm 5.22$ hari. Semakin lama masa kosong pada kambing dapat mempengaruhi masa laktasi dan produksi susu. Hal ini sesuai dengan pernyataan Makin dan Suharwanto (2012) bahwa selang beranak secara langsung dipengaruhi oleh masa kosong untuk setiap masa laktasi, sedangkan menurut Atabany (2013) masa kosong lebih dari 120 hari pada kambing PE betina menandakan adanya kelainan reproduksi. Tingginya nilai koefisien variasi hasil penelitian karena data masih sangat beragam dan sangat dipengaruhi oleh faktor manajemen.

Selang beranak merupakan penjumlahan dari masa kosong dan masa bunting. Masa bunting sudah tetap secara fisiologis dan tidak bisa dirubah waktunya. Masa kosong sesuai manajemen yang merupakan akumulasi dari interval kawin pertama setelah beranak dan service per conception (S/C). Sehingga perlu dilakukan perbaikan manajemen untuk mengurangi keberagaman masa kosong. Masa kosong yang panjang perlu adanya perbaikan terhadap manajemen pencatatan, perkawinan dan ketelitian yang baik dalam pengamatan munculnya estrus (Awan et al. 2016).

Berdasarkan statistik dapat dilihat pada Tabel 9, hasil analisis uji Kruskal wallis menunjukkan tipe kelahiran pengaruhnya tidak nyata terhadap masa kosong $\mathrm{H}_{\text {hitung }}<\mathrm{H}_{\text {tabel }}$ $(0.330<2.215)$. Masa kosong adalah indikator kesuburan ternak perah yang variasinya dipengaruhi oleh biologis ternak dan keadaan lingkungan. Masa kosong yang beragam

Tabel 8. Rataan masa kosong kambing perah Saanen

\begin{tabular}{lcccccc}
\hline Tipe Kelahiran & $\mathrm{n}$ & Masa Kosong (hari) & Std. dev & Koefisien variasi (\%) & Minimum (hari) & Maksimum (hari) \\
\hline Tunggal & 35 & 205.31 & 117.67 & 57.31 & 63 & 512 \\
Kembar 2 & 29 & 189.10 & 227.22 & 120.16 & 59 & 1296 \\
Kembar 3 & 9 & 276.67 & 240.38 & 86.88 & 53 & 665 \\
\hline
\end{tabular}


Tabel 9. Hasil statistik uji kruskal wallis masa kosong dari tipe kelahiran tunggal, kembar dua, dan kembar tiga

Kruskal wallis rank

\begin{tabular}{llcc}
\hline & Tipe Kelahiran & N & Mean Rank \\
\hline Masa kering & Tunggal & 35 & 40.20 \\
& Kembar dua & 29 & 32.47 \\
& Kembar tiga & 9 & 39.17 \\
& Total & 73 & \\
\hline
\end{tabular}

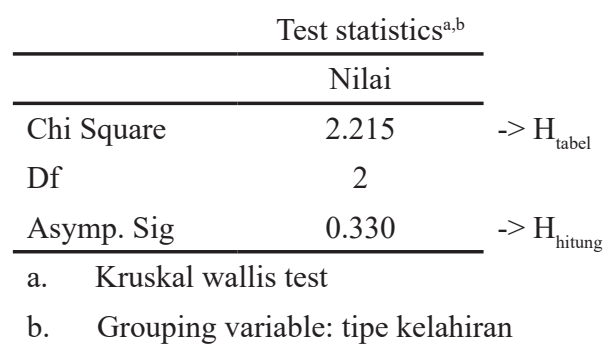

karena terkait kondisi mikroklimat (suhu, kelembaban dan curah hujan) yang mempengaruhi fisiologis ternak, faktor kesehatan, nutrisi, dan tatalaksana pemeliharaan (Setiawan et al. 2014).

\section{Pengaruh Tipe Kelahiran terhadap Selang Beranak}

Selang Beranak adalah waktu yang dibutuhkan seekor induk dari beranak hingga beranak selanjutnya. Deskripsi data selang beranak kambing Saanen dari tipe kelahiran tunggal, kembar dua dan kembar tiga di PT Fajar Taurus dilihat pada Tabel 10 .

Berdasarkan deskripsi data Tabel 10, rataan selang beranak induk tipe kelahiran kembar tiga adalah terpanjang $426.67 \pm 240.38$ hari, koefisien variasi $56.34 \%$, sedangkan selang beranak kelahiran tunggal $355.31 \pm 117.67$ hari, koefisien variasi $33.12 \%$, lebih pendek daripada selang beranak tipe kelahiran kembar dua 339.10 \pm 227.22 hari, koefisien variasi $67.01 \%$. Selang beranak induk dari ketiga tipe kelahiran pada tempat penelitian lebih panjang dari hasil penelitian Rizki et al. (2019) di BBPTU HPT Baturraden, rataan selang beranak kambing Saanen adalah 284.27 hari. Hasil penelitian Peniche et al. (2012) selang beranak kambing Saanen adalah 373-387 hari.

Menurut Harland dan Attfield (2020) pada kondisi pakan dan manajemen yang baik kambing Saanen di daerah tropis memiliki selang beranak yang beragam, yaitu dari 260-290 hari. Keberagaman selang beranak terjadi karena keberagaman masa kosong. Lebih panjangnya selang beranak pada tempat penelitian disebabkan oleh masa kosong yang panjang. Kejadian masa kosong yang panjang, biasanya karena ternak kawin tapi terjadi kebuntingan rendah, sehingga perlu dilakukan perbaikan manajemen.
Karena manajemen reproduksi yang baik dapat dilihat dari tingkat pencapaian performa sifat-sifat reproduksi, diantaranya $\mathrm{S} / \mathrm{C}$, masa kosong dan selang beranak. Menurut Lubis (2016) pengetahuan peternak yang rendah tentang manajemen reproduksi seperti deteksi estrus dan waktu mengawinkan ternak dapat mempengaruhi panjangnya selang beranak. Rendahnya capaian performa reproduksi tersebut ditandai oleh kawin pertama ternak yang rendah, angka $\mathrm{S} / \mathrm{C}$ besar, menyebabkan jumlah waktu dari beranak sampai bunting menjadi panjang.

Tabel 11. Hasil statistik uji kruskal wallis selang beranak dari tipe kelahiran tunggal, kembar dua, dan kembar tiga

Kruskal wallis rank

\begin{tabular}{llcc}
\hline & Tipe Kelahiran & N & Mean Rank \\
\hline Masa kering & Tunggal & 35 & 40.20 \\
& Kembar dua & 29 & 32.47 \\
& Kembar tiga & 9 & 39.17 \\
& Total & 73 & \\
\hline
\end{tabular}

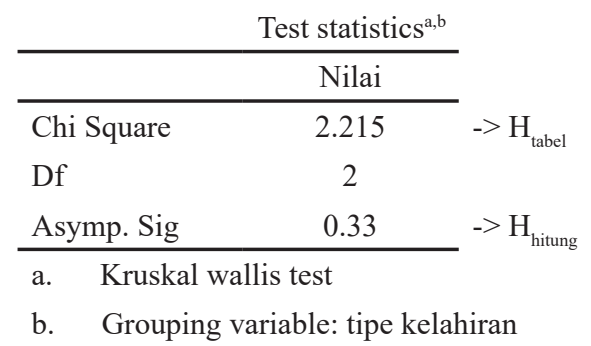

Berdasarkan statistik dapat dilihat pada Tabel 11, hasil analisis uji Kruskal wallis menunjukkan tipe kelahiran pengaruhnya tidak nyata terhadap selang beranak Hhitung $<$ Htabel $(0.330<2.215)$. Selang beranak dapat dipengaruhi oleh kemampuan peternak dan ternak, yaitu umur ternak, perkawinan setelah kelahiran, lama laktasi dan masa kering. Semakin bertambahnya umur ternak akan diikuti oleh terjadinya penurunan fungsi organ reproduksi terutama dalam memproduksi hormon-hormon yang diikuti semakin rendahnya fertilitas. Ternak kawin setelah kelahiran dipengaruhi oleh kemampuan peternak dalam mengawasi munculnya estrus, IB jadi tidak tepat. Lama laktasi erat kaitannya dengan tingginya produksi susu, karena kualitas hijauan yang baik dan perlakuan frekuensi pemerahan yang teratur. Masa kering yang panjang, artinya akan terjadi penimbunan cadangan energi di dalam hati dan saluran reproduksi, akibatnya terjadi kegemukan pada ternak, ternak akan mudah stress. Kondisi ini dapat memicu infeksi penyakit dan akan bermasalah dengan siklus estrus (Prasetiyo et al. 2015).

Tabel 10. Rataan selang beranak kambing perah Saanen

\begin{tabular}{lcccccc}
\hline Tipe Kelahiran & $\mathrm{n}$ & Selang Beranak (hari) & Std. dev & Koefisien variasi (\%) & Minimum (hari) & Maksimum (hari) \\
\hline Tunggal & 35 & 355.31 & 117.67 & 33.12 & 213 & 662 \\
Kembar 2 & 29 & 339.10 & 227.22 & 67.01 & 209 & 1446 \\
Kembar 3 & 9 & 426.67 & 240.38 & 56.34 & 203 & 815 \\
\hline
\end{tabular}




\section{KESIMPULAN}

Tipe kelahiran berpengaruh terhadap masa kering namun tidak berpengaruh terhadap produksi susu, lama laktasi, masa kosong dan selang beranak. Tipe kelahiran kembar tiga memiliki masa kering lebih pendek dibandingkan tipe kelahiran tunggal dan kembar dua. Hasil penelitian ini dapat digunakan dalam optimalisasi manajemen pemeliharaan kambing Saanen.

\section{DAFTAR PUSTAKA}

Anggraeni, A. 2012. Perbaikan genetik sifat produksi susu dan kualitas susu sapi Friesian Holstein melalui seleksi. Wartazoa. 22(1): 1-11.

Assan, N. 2020. Effect of litter size (birth type) on milk and composition in goats and sheep production. J. Anim. Sci. 9(7): 635-643. ISSN 2322-1704. DOI: 10.14196/ sjas.v9i7.1511.

Atabany, A. 2013. Panduan Sukses Beternak Kambing Peranakan Etawah. Bogor (ID): IPB Press.

Awan, J. S., A. Atabany, \& B. P. Purwanto. 2016. Pengaruh umur beranak pertama terhadap performa produksi susu sapi Friesian Holstein di BBPTU-HPT Baturraden. J. Ilmu Produksi dan Teknologi Hasil Peternakan. 4(2): 306-311. ISSN 2303-2227.

Bermejo, J. V. D., F. A. L. Pérez, F. J. N. González, J. M. L. Jurado, J. F. Álvarez, \& L. T. da Gama. 2020. Conditioning factors of linearized wood's function lactation curve shape parameters, milk yield, fat and protein content in Murciano-Granadina primiparous does. J. Anim. 10(11): 2115. DOI:10.3390/ ani10112115.

Beth, A. M, \& D. L. Christopher. 2019. Current status of global dairy goat production: an overview. J. Anim. Sci. 32(8): 1219-1232. DOI.10.5713/ajas 19.0253.

Collier, R. J. 2011. Effects of continuous milking, bST and early-lactation milking frequency on mammogenesis, milk yield and composition in primiparous cows. J. Dairy Sci. 87(1): 425.

Faye, B., \& G. Konuspayeva. 2012. The sustainability challenge to the dairy sector the growing importance of non-cattle milk production world wide. Int. Dairy J. 24 (12): 50-56. DOI: 10.1016/j.idairyj.2011.12.011.

Fernandez, A. B. 2013. Goat milk production and lactation duration of Nubian, Saanen, and Toggenburg genotypes under restricted grazing and concentrate supplementation. Abanico Veterinario. 3: 30-35.

Fitriyanto, Y. A., Triana, \& U. Sri. 2013. Kajian viskositas dan berat jenis susu kambing Peranakan Etawah (PE) pada awal, puncak, dan akhir laktasi. J. Ilmiah Pet. 1: 299-306.

Gaddour, A., S. Najari, \& M. Ouni. 2007. Dairy performances of the goat genetic groups in the Southern Tunisian. Agric. J. 2(2): 248-253.

Goetsch, A. L., S. S. Zeng, \& T. A. Gipson. 2011. Factors affecting goat milk production and quality. Small Rumin. Res. 101: 55-63.

Haldar, A., P. Pal, M. Datta, R. Paul, K. P. Saumen, D.
Majumdar, C. K. Biswas, \& S. Pan. 2014. Prolificacy and its relationship with age, body weight, parity, previous litter size and body linear type traits in meattype goats. Asian-Australas J. Anim. Sci. 27(5): 628634. DOI: 10.5713/ajas.2013.13658.

Harland, H., \& D. Attfield. 2020. Understanding dairy goat production. Department of Agriculture National Dairy Authority. Philippines. https://www.goatworld. com/articles/udgp.shtml. [23 Januari 2021].

Hernandez, F., L. Elvira, J. V. Gonzalez, S. Martin, \& Astiz. 2012. Influence of dry period length on reproductive performance and productivity of Lacaune dairy sheep under an intensive management system. J. Dairy Res. 79(3): 352-360.

Ince, D. 2010. Reproduction performance of Saanen goats raised under extensive conditions. African J. Biotechnology. 9(48): 8253-8256.

Kusaka. H., H. Miura, M. Kikuchi, \& M. Sakaguchi. 2017. Incidence of double ovulation during the early postpartum period in lactating dairy cows. J. Theriogenology. 91:98-103.

Liang, B. J., \& P. Paengkoum P. 2019. Current status, challenges and the way forward for dairy goat production in Asia-conference summary of dairy goats in Asia. Asian-Australasian J. of Anim. Sci. 32(8): 1233-1243. DOI: https://doi.org/ 10.5713/ajas.19.0272.

Lopez-Gatius, B. F., C. Andreu-Vázquez, R. MurNovales, \& V. E. Cabrera. 2017. The dilemma of twin pregnancies in dairy cattle. A Review of Practical Prospects. Livest Sci. 197: 12-16.

Lubis, E. M. 2016, Efisiensi reproduksi kambing Peranakan Etawa di lembah Gogoniti Farm di Desa Kemirigede Kecamatan Kesamben Kabupaten Blitar. J. Aves. 10 (1): 28-34. p-ISSN 1907-1914 e-ISSN 2503-4251.

Makin, M. 2014. Manajemen Ternak Kambing Perah. Bandung (ID): Fakultas Peternakan Universitas Padjadjaran.

Makin, M., \& D. Suharwanto. 2012. Performans sifat-sifat produksi susu dan reproduksi sapi perah Fries Holland di Jawa Barat. J. Ilmu Ternak. 12(2): 39-44. https:// doi. org/10.24198/ jit.v12i2.5128.

Margatho, G., V. R. Estevez, H. Quintas, \& J. Simoes. 2019. The effects of reproductive disorders, parity, and litter size on milk yield of Serrana goats. J. Anim. 9(11): 968. doi: 10.3390/ani9110968.

Pan, S., C. H. Biswas, D. Majumdar, D. Sengupta, A. Patra, S. Ghosh, \& A. Haldar. 2015. Influence of age, body weight, parity and morphometric traits on litter size in prolific Black Bengal goats. J. of Applied Anim. Res. 43(1): 104-111. https://doi.org/10.1080/09712119 .2014.928623.

Peniche, T. B. G. H., H. Montaldo, M. V. Posadas, G. R. M. V. Wiggans, S. M. Hubbard, J. A. T. Vazquez, \& L. Shepard. 2012. Breed differences over time and heritability estimates for production and reproduction traits of dairy goats in the United States. J. of Dairy Sci. 95(5): 2707-2717.

Prasetiyo, Y., M. Hartono, \& Siswanto. 2015. Calving interval sapi perah laktasi di Balai Besar Pembibitan 
Ternak Unggul dan Hijauan Pakan Ternak (BBPTUHPT) Baturraden Purwokerto Jawa Tengah. J. Ilmiah Pet. Terpadu. 3(1): 7-14.

Rizki, E. A. R, H. Indrijani, \& B. S. Lia. 2019. Analisis perbandingan performa reproduksi kambing Saanen dan Peranakan Etawa. J. Ilmu Pet. (JANHUS). 3(2): 27-32.

Sánchez, I., R. D. Martínez, G. Torres, C. M. Becerril, A. A. Mastache, J. Suárez, \& M. Rubio. 2006. Producción de leche y curvas de lactancia en tres razas de cabras en el trópico seco de México [Milk production and lactation curves in three breeds of goats in the dry tropics of Mexico]. Vet Méx. 37: 493-502.

Setiawan, R., K. Hidajat, \& D. C. Budinuryanto. 2014. Studi asosiasi antara masa kosong (days open) terhadap produksi susu dan kerugian ekonomi pada peternakan sapi perah di Kabupaten Garut. J. Ilmu Ternak. 1(4): 17-21.

Silva, C. M. B. A., B. B. Souza, P. A. Brando, P. V. T. Marinho, \& T. M. A. Benicio. 2011. Effect of the semiarid climatic conditions on the physiological behavior of F1 Saanen x Boer crossbred goats. Revista Caatinga. Mossoró. 24(4): 195-199.
Simões, J., \& A. F. A. Pires. 2017. Reproductive disorders in Portuguese Serrana goats and its effects on milk production. Rev. Colomb. Cienc. Pecu. 31(1): 64-71. doi: 10.17533/udea.rccp.v31n1a08.

Tiezzi, F., C. Maltecca, A. Cecchinato, M. Penasa, \& G. Bittante. 2012. Genetic parameters for fertility of dairy heifers and cows at different parities and relationships with production traits in first lactation. J. Dairy Sci. 95 (23063160): 7355-7362.

Yilmaz, M., H. E. Bardakcioglu, \& T. Altin. 2016. Comparison of some body measurements for Saanen goats. Scientific Papers Animal Science Series. Series: Lucrări Ştiinţifice-Seria Zootehnie. 65: 134-137.

Zobel, G., D. M. Weary, K. E. Leslie, \& M. A. G. Von Keyserlingk. 2015. Invited review: Cessation of lactation: Effect on animal welfare. J. Dairy Sci. 98(12): 8263-8277. 